\title{
Cellular Ceramics Produced from Ceramic Shell: Processing and Characterization
}

\author{
Naiane Paiva Stochero ${ }^{a}$, Elisângela Guzi de Moraes ${ }^{a}$, Antonio Pedro Novaes de Oliveira ${ }^{a}$ \\ aPrograma de Pós-Graduação em Ciência e Engenharia de Materiais (PGMAT), Laboratório de \\ Materiais Vitrocerâmicos (VITROCER), Universidade Federal de Santa Catarina (UFSC), Campus \\ Universitário, Caixa Postal 476, 88040-900, Florianópolis, SC, Brasil
}

Received: December 15, 2016; Revised: October 05, 2017; Accepted: October 06, 2017

\begin{abstract}
In this work, ceramic shell (mullite source), an industrial solid waste from the lost-wax casting process, after crushing and milling steps, was used and evaluated as an alternative raw material source for the production of cellular ceramics for high temperature applications $\left(>1400{ }^{\circ} \mathrm{C}\right)$. The obtained ceramic shell powder, with particle size distribution $\left(\mathrm{d}_{50}<2 \mu \mathrm{m}\right)$ suitable for the production of ceramic foams, was characterized from the point of view of their physical, chemical, morphological and crystallographic properties. Samples were prepared and obtained by direct foaming and gelcasting routes, dried at room temperature and then fired in two steps $\left(650^{\circ} \mathrm{C} / 2 \mathrm{~h}\right.$ and $\left.15500^{\circ} \mathrm{C} / 2 \mathrm{~h}\right)$, and cooled in the furnace to room temperature. The effects of solids loading ( 35 and 42 vol. \%) and stirring velocity (500 and $2000 \mathrm{rpm}$ ) on the cellular structure (pore size distribution and porosity) and mechanical properties of the produced ceramic shell foam samples were evaluated. The results showed that it is possible to obtain ceramic foams based on mullite-zirconite, with pore sizes between 100 and 900 $\mu \mathrm{m}$, porosities up to $77 \%$ and compressive strength varying from 3 to $20 \mathrm{MPa}$.
\end{abstract}

Keywords: Cellular ceramics, ceramic shell, wastes, porous materials

\section{Introduction}

In recent years, there is a growing interest in the development of high performance ceramics possessing cell structure, due to their exceptional combination of properties such as low density, low thermal conductivity, high specific strength, high permeability and high tortuosity of flow paths, high thermal shock resistance, high porosity, high specific surface area, and so forth. In addition, the advantage of a higher temperature and environmental stability compared with conventional polymers and metals foams. These engineering materials find application in different technological areas, for example, filtration of molten metals or particulate from exhaust gases, thermal and acoustic insulation, catalyst supports, radiant burners, among others ${ }^{1-6}$.

Cellular ceramics have potential in structural applications due to their design and tailored porosity $(>70 \%)$, pore size distribution, pore connectivity, allowing efficient optimization of the elastic modulus-weight ratio ${ }^{6,7}$.

The processing routes have great influence on the microstructure and properties of the cellular material. So, different manufacturing processes such as replica, sacrificial template, direct foaming and gelcasting, have been used to produce cellular ceramics with tailored properties ${ }^{2,6}$.

The direct foaming technique consists of incorporating air into a stable suspension by mechanical stirring to produce air bubbles. The total porosity of the foams is proportional to the amount of air incorporated in the ceramic suspension during the foaming process. In order to avoid the collapsing

*e-mail: naianestochero@hotmail.com of the wet foam, special additives, long-chain surfactants and biomolecules, such as lipids and proteins, can adsorbed at air-liquid bubble interface to stabilize the liquid foams by decreasing the interfacial energy ${ }^{2}$. Once the liquid foam morphology is stabilized, it is consolidated by gelling. One of the main advantages of this technique is the possibility to get foams with open or closed cells, within a wide range of pore sizes, which have dense struts containing less defects and improved green strength. Another advantage is the use of non-toxic gelling agents, which do not require atmosphere control, and are relatively low $\operatorname{cost}^{6-9}$.

Recent technological strategies suggest the development of more efficient industrial processes that contribute to the reduction of energy consumption and the wise use of natural resources.

According to Carvalho et al. ${ }^{10}$, the valorization of industrial wastes for the production of new materials has attracted great interest of researchers, since there is a very large quantity of residues characterized by a strong potential for reuse as raw materials. In fact, the ceramic shell from the lost-wax casting process is classified as non-hazardous material and exhibits similar features to those of mullite, such as good chemical stability, low thermal conductivity and good thermal shock resistance. In addition, the ceramic shell waste is generated in a quite significant volume in Brazil, i.e., 50 to $100 \mathrm{t}$ per month. Furthermore, it has been successfully used as an alternative raw material source for the production of ceramic filters for molten metals and additives for concrete components ${ }^{11}$. 
In this context, cellular ceramics from ceramic shell with optimized properties were developed by direct foaming and gelcasting routes, in order to minimizing the environmental problems caused by the inadequate disposal of this waste. The results showed that it is possible to obtain mullite-zirconite based cellular ceramic materials with pore sizes between 100 and $900 \mu \mathrm{m}$, porosities up to $77 \%$ and compressive strength varying from 3 to $20 \mathrm{MPa}$.

\section{Materials and Methods}

The process for fabricating the ceramic shell foams is given by the flowchart in Figure 1, as described in detail in the following sections.

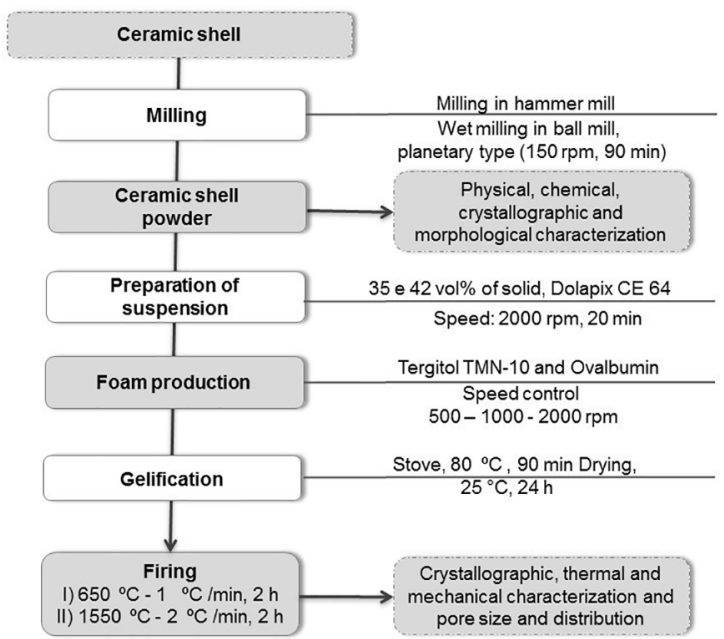

Figure 1. Flowchart for production of ceramic shell foams by direct foaming and gelcasting processes.

\subsection{Ceramic shell powder preparation and characterization}

The ceramic shell waste (fragments with average sizes of $50 \mathrm{~mm}$ and moisture content of $0.6 \%$, supplied by Precicast Precision Casting Company - Brazil), was initially crushed in a hammer mill (SERVITECH CT-058) to average size $<1$ $\mathrm{mm}$, and then wet milled (residue:water; 4:6) in a planetary mill (SERVITECH CE-242) containing alumina grinding media for $90 \mathrm{~min}$ at $150 \mathrm{rpm}$. According to Carvalho et al. ${ }^{10}$, this grinding procedure presents greater efficiency in terms of the ceramic shell particle size reduction. The average particle size distribution was determined using a laser scattering particle size analyzer (Master Sizer 3000 , Malvern). The particle morphology was evaluated by a scanning electron microscopy (SEM), JEOL JSM (model 6390LV). Chemical composition was determined by X-ray fluorescence spectroscopy (FRX, Philips PW 2400) and crystalline phases were determined by $\mathrm{X}$-ray diffractometry, (Philips X'pert - with $\mathrm{Cu} K \alpha, 40 \mathrm{kV}, 40 \mathrm{~mA}, 0.05^{\circ}, 2 \mathrm{~s}$ ).

\subsection{Ceramic shell suspension preparation}

In order to obtain ceramic shell foams by direct foaming and gelcasting processes, an aqueous suspension was prepared with 35 or 42 vol.\% of ceramic shell powder, 1.5 vol. $\%$ of low molecular weight polyacrylic acid (320 $\mathrm{g} / \mathrm{mol}$ ) as dispersant, commercially available as Dolapix CE 64 (Zschimmer \& Schwarz). The homogenization was performed in a laboratory mixer (IKA, RW 20 S32) with a $30 \mathrm{~mm}$ dispersing tool operating at a stirring velocity of $2000 \mathrm{rpm}$ for $20 \mathrm{~min}$.

\subsection{Ceramic shell foams preparation and characterization}

Ceramic shell foams were prepared by adding 0.1 vol.\% of Tergitol TMN-10 (Sigma-Aldrich, 90\% purity) as surfactant, and added 5 wt.\% of Ovalbumin (Sigma-Aldrich, $62-88 \%$ purity) based on solid content, as gelling agent to the ceramic suspension containing different solids loading under mechanical stirring for $5 \mathrm{~min}$. In order to investigate the influence of stirring velocity on pore structure and porosity of ceramic foams, stirring velocities of $500 \mathrm{rpm}, 1000 \mathrm{rpm}$ and $2000 \mathrm{rpm}$ were applied.

The wet foams were poured in an aluminum molds (78 $\mathrm{mm}$ in diameter), and subjected to a small vibration, in order to eliminate defects. Subsequently, the foams were consolidated at $80{ }^{\circ} \mathrm{C}$ for $20 \mathrm{~min}$ in an electric oven and dried for $24 \mathrm{~h}$ in air. Firing was conducted in two steps: first the samples were pre-calcinated in a muffle (JUNG - model $0213)$, at $650{ }^{\circ} \mathrm{C}\left(2 \mathrm{~h}, 1^{\circ} \mathrm{C} / \mathrm{min}\right.$ heating rate $)$, to decompose the organic phase; secondly, the samples were heated to $1550{ }^{\circ} \mathrm{C}\left(2 \mathrm{~h}, 2^{\circ} \mathrm{C} / \mathrm{min}\right.$ heating rate $)$, in a high temperature furnace (JUNG - model 0917).

The true density $\left(\rho_{t}\right)$ of powdered samples (crushed and milled cell walls) was determined by using a helium pycnometer (Quantachrome Ultra Pycnometer 1000). The apparent density $\left(\rho_{a}\right)$ of fired foam samples was determined by relating their geometrical measurements, obtained using a caliper (Mitotoyo, accuracy $\pm 0.01 \mathrm{~mm}$ ), and their masses (Shimadzu AX200 at $0.001 \mathrm{~g}$ ). The relative density $\left(\rho_{r}\right)$ was calculated, relating the apparent densities and the true densities of the samples. From measurements of geometrical and true densities the porosity $(\varepsilon)$ of fired ceramic foams was calculated according to Equation 1.

$$
\varepsilon=\left(1-\frac{\rho_{a}}{\rho_{t}}\right) \times 100
$$

The morphology and cellular structure (pore size distribution) of the fired ceramic foams was investigated by scanning electron microscopy (SEM, JEOL JSM - model 6390LV). The linear intercept method (ASTM E112-12) was used to estimate the pore size distribution from the micrographs (four pictures for different solids content ( 35 and $42 \mathrm{vol} . \%$ ), and stirring velocities (500, 1000 and $2000 \mathrm{rpm})$, were measured making a total of 
150 chords/sizes for each condition), using an image analysis program (Axio Vision LE). The average values were obtained considering stereological relations (ASTM D3576-98).

The thermal conductivity of the ceramic shell foams was measured in a conductivity analyzer (TCI Thermal Conductivity Analyzer C-THERM technologies). Disks with nominal diameter of $25 \mathrm{~mm}$ x $5 \mathrm{~mm}$ (thickness) were tested, and three measurements were taken on each flat surface of the samples.

The compressive strength of the fired ceramic foams was measured on samples with nominal dimensions of $10 \times 10 \times 10$ $\mathrm{mm}$ using a universal testing machine (EMIC, model DL $2000 ; 1.0 \mathrm{~mm} / \mathrm{min}$ cross-head speed), according to ASTM C133-97. Three to five specimens cut from larger $50 \mathrm{x}$ $12 \mathrm{~mm}$ disks, were tested for each sample. It is important to note that EVA sheets (ethylene-vinyl acetate) of $2 \mathrm{~mm}$ thickness were placed in the interface between sample faces and cell load in order to assure homogeneous load transfer and compensate for any surface irregularities.

\section{Results and Discussion}

The particle size distribution of the ceramic shell powder is presented in Figure 2 for different milling processes. After the first step of milling using a hammer mill, a wide particle size distribution (from $\mathrm{d}_{10}=1.1 \mu \mathrm{m}_{\text {to }} \mathrm{d}_{90}=372 \mu \mathrm{m}$ ) is observed (Figure 2 (a)). After 90 min of wet milling using a planetary mill, the resulting powder exhibited sizes ranging from $\mathrm{d}_{10}$ $=0.63 \mu \mathrm{m}$ to $\mathrm{d}_{90}=5.56 \mu \mathrm{m}$ showing a significant reduction on the mean particle size, approximately $96 \%$, related to the initial size, characterizing thus a narrower particle size distribution profile according to the blue curve in Figure 2 (a). Effectively, narrower particle size distribution allows a better control of homogenization of the suspensions and consequently of the cellular structure of the ceramic foams (pore size distribution, cell struts with high packing density).

Figure 2 (b) shows the morphology of the finely distributed milled powders, as well the presence of agglomerated with irregular morphology, generated after planetary milling. The theoretical density of the ceramic shell powder determined by gas pycnometry, was $2.99 \mathrm{~g} / \mathrm{cm}^{3}$.

According to Colombo (2006), the ceramic foams processing begins with the selection of suitable ceramic powders, as well as, with the preparation of stable suspensions, for which, ceramic powders with sizes below of $3 \mu \mathrm{m}$ are required. Consequently, defects free ceramic structures are produced by low temperature sintering ${ }^{6,12}$.

Chemical composition of the ceramic shell is shown in Table 1. Observe that it consists mainly of $\mathrm{Al}_{2} \mathrm{O}_{3}, \mathrm{SiO}_{2}$, $\mathrm{ZrO}_{2}$ and small amounts of residual oxides present in the raw materials used in the manufacture of the ceramic shell, as well, from the process of alloy casting, or impurities from the milling processes.

Figure 3 shows a XRD diffraction pattern of the as received ceramic shell. The main peaks were attributed to the crystalline phases of mullite (JCPDS; 01-079-1454) and zirconium silicate (JCPDS; 01084-1560). This is in good agreement with Table 1 , chemical composition of the ceramic shell.
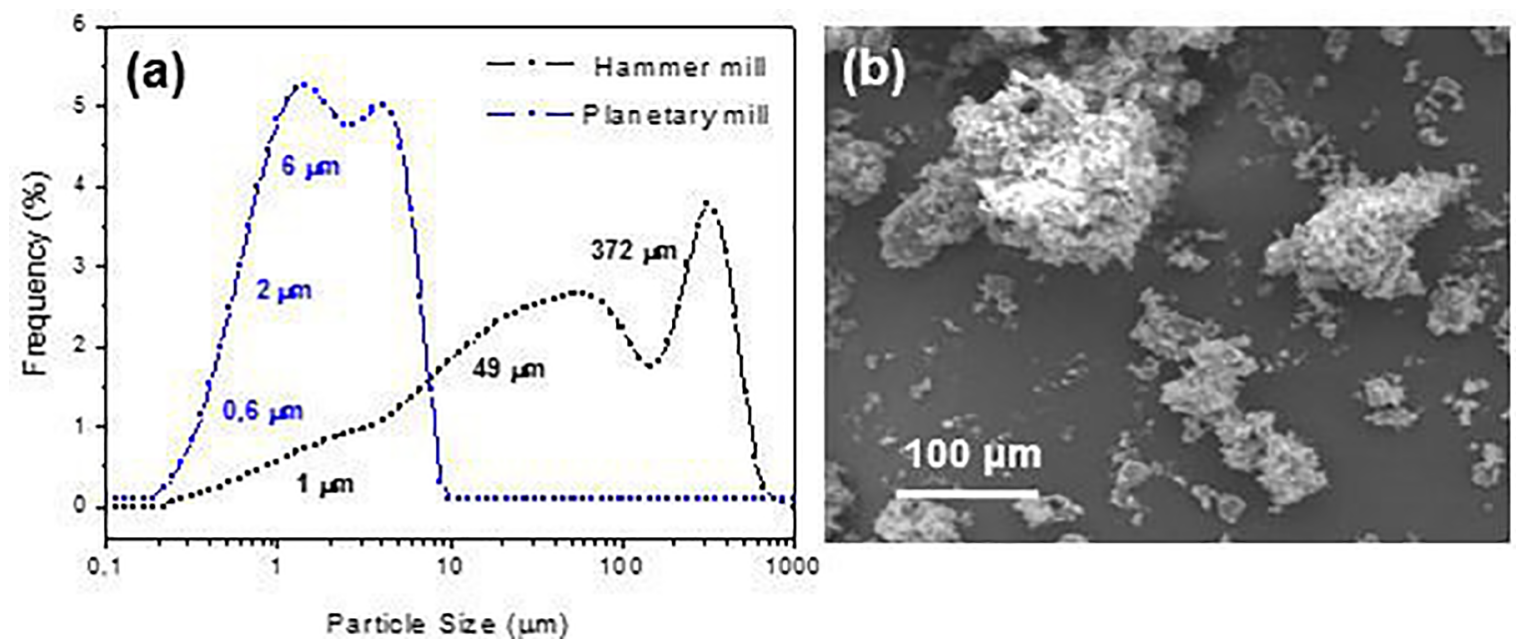

Figure 2. (a) Particle size distribution curves of the ceramic shell powders obtained from of different milling processes; (b) SEM micrograph of the ceramic shell powder resulting from the final milling.

Table 1. Chemical composition of the ceramic shell.

\begin{tabular}{cccccccccc}
\hline \multicolumn{10}{l}{ Constituent oxides (wt.\%) } \\
\hline $\mathrm{SiO}_{2}$ & $\mathrm{Al}_{2} \mathrm{O}_{3}$ & $\mathrm{ZrO}_{2}$ & $\mathrm{Fe}_{2} \mathrm{O}_{3}$ & $\mathrm{~K}_{2} \mathrm{O}$ & $\mathrm{TiO}_{2}$ & $\mathrm{CaO}$ & $\mathrm{Na}_{2} \mathrm{O}$ & Others & $*$ L.O.I. \\
51.0 & 39.1 & 3.6 & 1.8 & 1.3 & 1.2 & 0.96 & 0.5 & $<0.8$ & 0.81 \\
\hline
\end{tabular}

*L.O.I.: Loss on Ignition. 


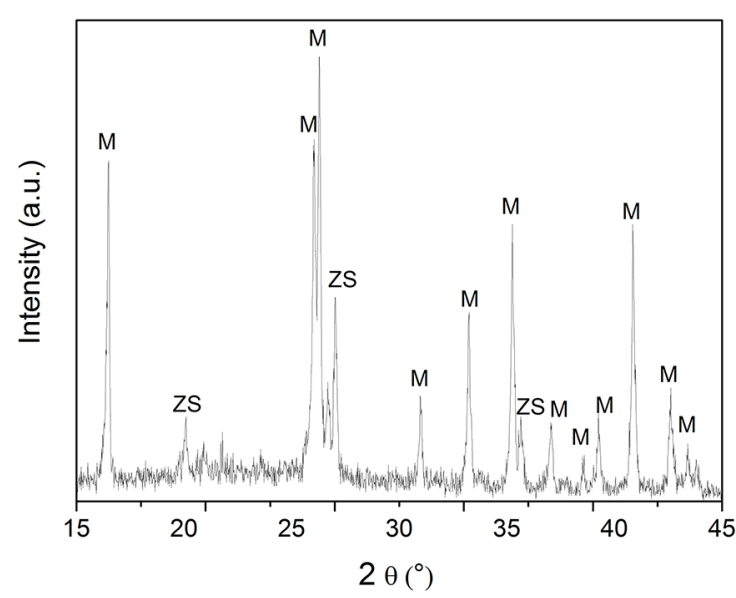

Figure 3. XRD of the as received ceramic shell. M: Mullite, ZS: Zirconium Silicate.

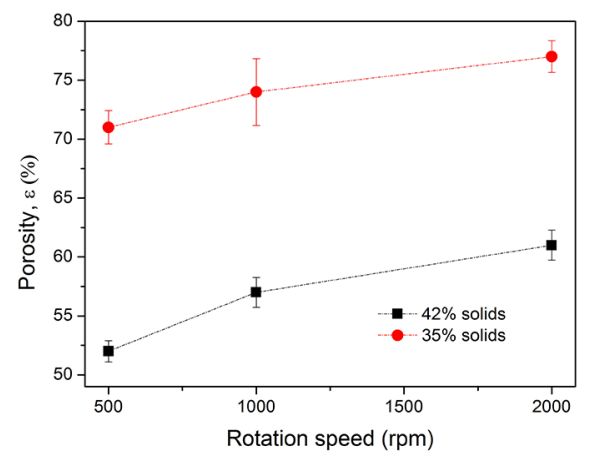

Figure 4. Influence of solids content and stirring velocity (rotation speed) on the porosity $(\varepsilon)$ of the fired ceramic shell foams.
Figure 4 shows the influence of the solids content and stirring velocity on the porosity of the ceramic shell foams (fired foams). It is possible to observe that porosity is significantly influenced by the decrease of solids content (from 42 vol.\% to 35 vol.\%), leading to decreasing on the suspension viscosity, consequently, the incorporation of air by mechanical stirring and ceramic shell foam formation is enhanced. Ceramic shell foams containing 35 vol. $\%$ of solids loading exhibit porosities ranging from $71 \%$ to $77 \%$, while that containing $42 \mathrm{vol} . \%$ of solids content exhibit porosities ranging from $52 \%$ to $61 \%$, as a result of increased viscosity.

Furthermore, porosity increase with stirring velocity, also as a consequence of the development in the interconnectivity between pores ${ }^{13}$.

Figure 5 shows the typical interconnected microstructure of the fired ceramic shell foams containing $35 \mathrm{vol} . \%$ of solids, 0.1 vol. $\%$ of Tergitol TMN-10, and 5 wt.\% of Ovalbumin, resulting from controlled variation of stirring velocity. The average pore size decreases from $450 \mu \mathrm{m}$ to $395 \mu \mathrm{m}$ and $354 \mu \mathrm{m}$, when the stirring velocity increases from $500 \mathrm{rpm}$ to $1000 \mathrm{rpm}$ and $2000 \mathrm{rpm}$, respectively (Figure 5 (a-c)). In addition, a narrower pore size distribution is observed from the histograms associated with each sample condition.

Similar behavior was observed for ceramic shell foams containing $42 \mathrm{vol} . \%$ of solids content. The presence of spherical pores uniformly distributed in the defect free matrix is verified. The average pore size decreases from $246 \mu \mathrm{m}$ to $183 \mu \mathrm{m}$ and $165 \mu \mathrm{m}$, when the stirring velocity increases from $500 \mathrm{rpm}$ to $1000 \mathrm{rpm}$ and $2000 \mathrm{rpm}$, respectively (Figure 6 $(\mathrm{a}-\mathrm{c}))$. Note that these values are lower than that for ceramic shell foams containing $35 \mathrm{vol} \% \%$ of solids content.
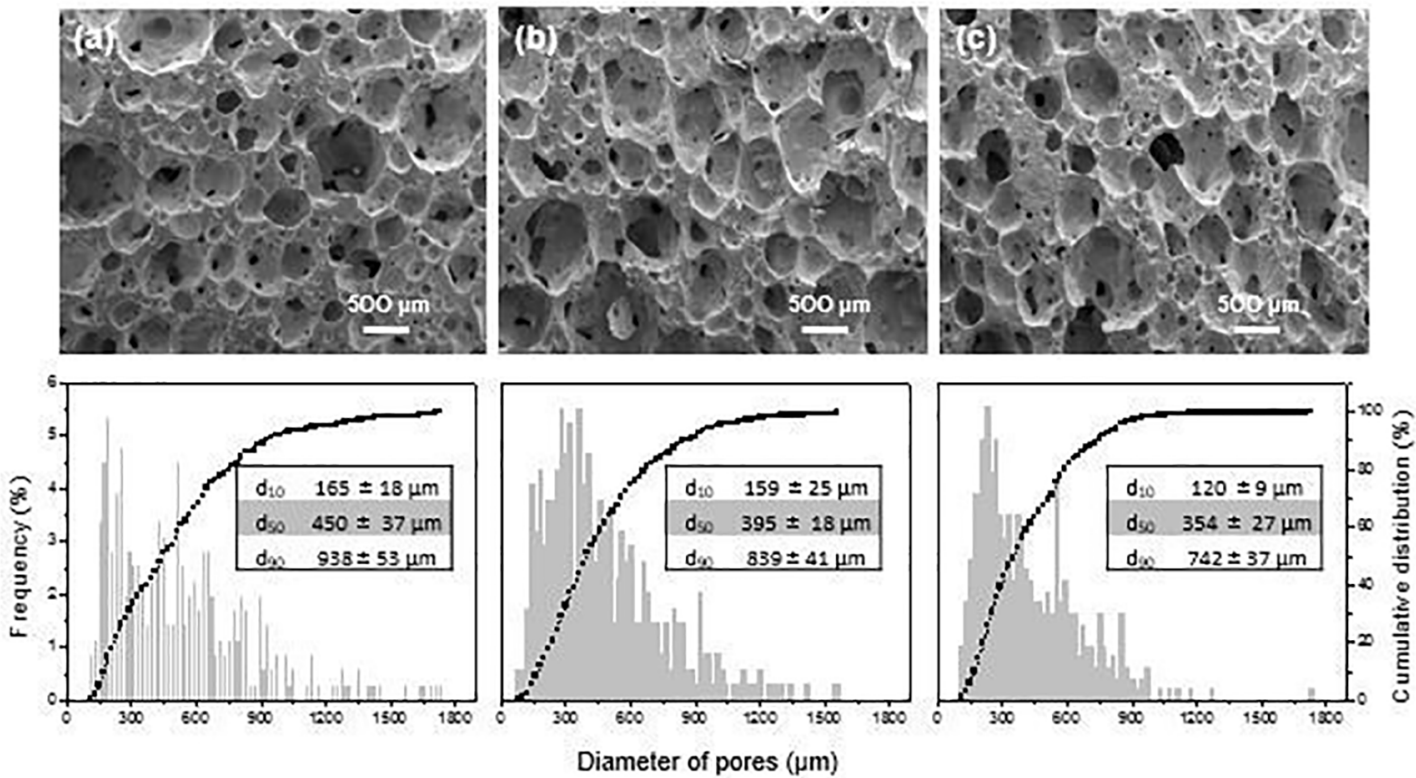

Figure 5. SEM micrographs of the pore structure of the fired ceramic shell foams containing $35 \mathrm{vol} . \%$ of solids, resulting from the controlled variation of the stirring velocity:(a) $500 \mathrm{rpm}$, (b) $1000 \mathrm{rpm}$ e (c) $2000 \mathrm{rpm}$ for $5 \mathrm{~min}$, as well as the pore size distribution (histograms) associated with each sample condition. 

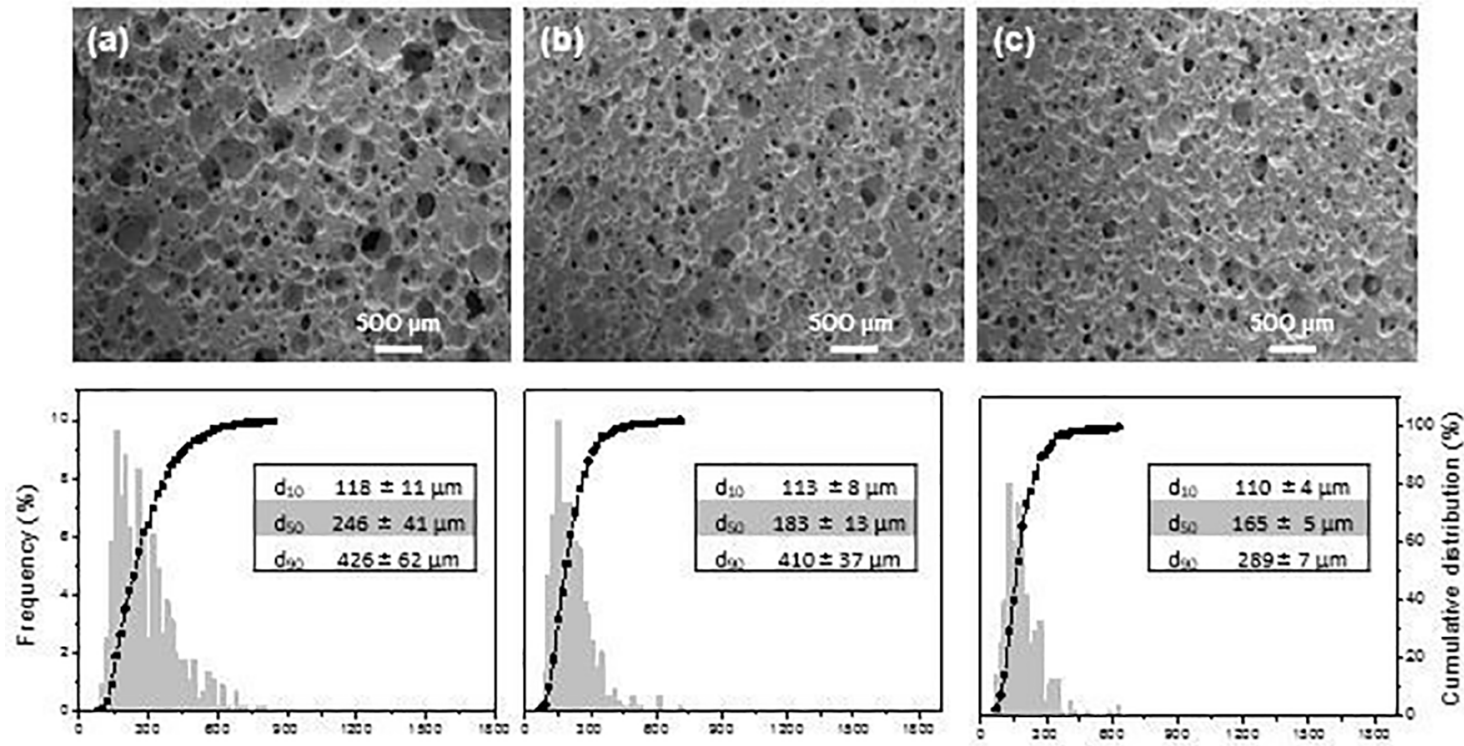

Diameter of pores $(\mu \mathrm{m})$

Figure 6. SEM micrographs of the pore structure of the fired ceramic shell foams containing $42 \mathrm{vol} \%$ of solids, resulting from the controlled variation of the stirring velocity:(a) $500 \mathrm{rpm}$, (b) $1000 \mathrm{rpm}$ e (c) $2000 \mathrm{rpm}$ for $5 \mathrm{~min}$, as well as the pore size distribution (histograms) associated with each sample condition.

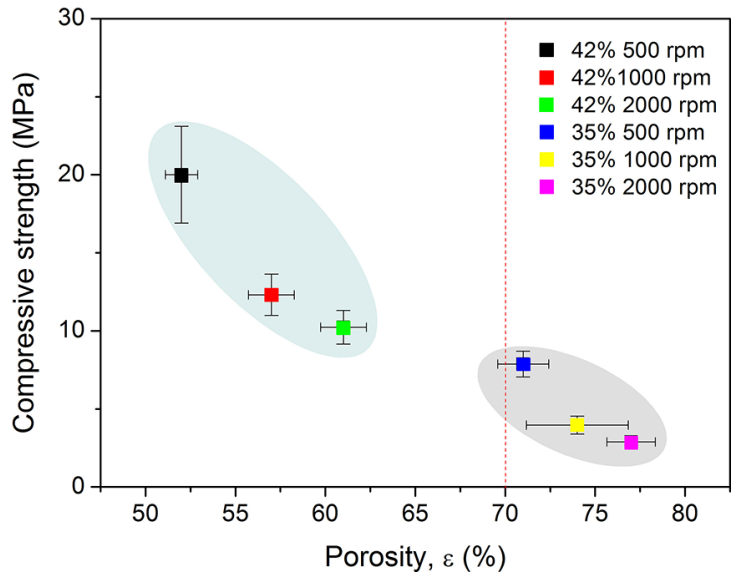

Figure 7. Compressive strength of the fired ceramic shell foams with 35 vol. $\%$ and 42 vol.\% of solids resulting from the controlled variation of the rotational speed (500 rpm, $1000 \mathrm{rpm}$ e $2000 \mathrm{rpm})$ as a function of porosity.

According to Sousa et al. ${ }^{14}$, the total porosity is essential for determining ceramic foam performance. Mechanical strength and thermal conductivity generally decreases with the increase of porosity. In addition, samples containing 35 vol. $\%$ and 42 vol. $\%$ of solids content, stirred at $2000 \mathrm{rpm}$ exhibit, respectively: $77 \%$ and $0.06 \pm 0.01(\mathrm{~W} / \mathrm{mK}) ; 52 \%$ and $0.09 \pm 0.01(\mathrm{~W} / \mathrm{mK})$, of porosity and thermal conductivity, respectively. According to Russell ${ }^{15}$, the thermal conductivity decreases with increasing of porosity, therefore, due to the presence of pores and weakly packed powder structures (porous cellular wall and struts), which minimizes the point of contact of the particles and consequently makes it more difficult for the phonons to be transferred ${ }^{16}$.

The compressive strength as a function of total porosity is reported in Figure 7 for ceramic shell foams with different solids content ( 35 vol. \% and 42 vol. $\%$ ) and stirred at different stirring velocities (500 rpm, $1000 \mathrm{rpm}$ and $2000 \mathrm{rpm}$ ). The values increased from $3 \mathrm{MPa}$ to $20 \mathrm{MPa}$, when the porosity decreased from $77 \%$ to $52 \%$, as a consequence of high strength struts. Furthermore, with the increase of stirring velocity, the ceramic foam develops a more interconnected structure, consequently the pore walls has higher porosity.

Nevertheless, the strength values for these samples were higher than those foams with similar composition and total porosity produced by replication methods (less than $<1 \mathrm{MPa})^{10}$.

\section{Conclusions}

Ceramic shell foams were obtained from direct foaming and gelcasting routes, with suitable microstructures for different engineering applications, especially those which require an adequate combination of permeability, refractoriness and mechanical strength, as in the case of radiant porous burners for instance. The main crystalline phases identified were mullite and zirconite. Varying processing parameters, such as solids content of slurry, stirring velocity, should allow tailoring of strut microstructure and porosity, in order to improve the mechanical properties. Ceramic shell foams with porosities up to $77 \%$ and pore sizes between $100 \mu \mathrm{m}$ 
and $900 \mu \mathrm{m}$ and compressive strengths of $3 \mathrm{MPa}$ to $20 \mathrm{MPa}$ were successfully obtained.

\section{Acknowledgements}

Authors are grateful to Precicast Precision Casting for the supply of the ceramic shell, CAPES, FAPESC/CNPq (Pronex Project, T.O.N. 17431/2011-9) by the financial support, and CNPq for granting a scholarship at Doctoral level (Process N 870554/1997-2).

\section{References}

1. Scheffler M, Colombo P. Cellular Ceramics: Structure, Manufacturing, Properties and Application. Weinheim: Wiley$\mathrm{VCH} ; 2005$.

2. Studart AR, Gonzenbach UT, Tervoort E, Gauckler LJ. Processing routes to macroporous ceramics: A review. Journal of the American Ceramic Society. 2006;89(6):1771-1789.

3. Gauckler LJ, Waeber MM, Conti C, Jacob-Duliere M. Ceramic Foam for Molten Metal Filtration. The Journal of the Minerals, Metals \& Materials Society. 1985;37(9):47-50.

4. Chen QZ, Rezwan K, Armitage D, Nazhat SN, Boccaccini AR. The surface functionalization of 45S5 Bioglass-based glass-ceramic scaffolds and its impact on bioactivity. Journal of Materials Science: Materials in Medicine. 2006;17(11):979987.

5. Chen QZ, Thompson ID, Boccaccini AR. 45S5 Bioglass ${ }^{\circledR}-$ derived glass-ceramic scaffolds for bone tissue engineering. Biomaterials. 2006;27(11):2414-2425.

6. Colombo P. Conventional and novel processing methods for cellular ceramics. Philosophical Transactions of the Royal Society. 2006;364(1838):109-124.
7. Barg S, Moraes EG, Koch D, Grathwohl G. New cellular ceramics from high alkane phase emulsified suspensions (HAPES). Journal of the European Ceramic Society. 2009;29(12): 2439-2446.

8. Ohji T, Fukushima M. Macro-porous ceramics: processing and properties. Journal International Materials Reviews. 2012;57(2):115-131.

9. Moraes EG, Li D, Colombo P, Shen Z. Silicon nitride foams form emulsions sintered by rapid intense thermal radiation. Journal of the European Ceramic Society. 2005;35(12):32633272 .

10. Carvalho AC, Raupp-Pereira F, Rodrigues Neto JB, Novaes de Oliveira AP. A new source for production of ceramic filters. Materials Letters. 2015;145:250-252.

11. Machado CF, Moravia WG. Caracterização do resíduo de casca cerâmica do processo de fundição por cera perdida para emprego como pozolana. In: IX Brazilian Symposium on Glass and Related Materials; 2012 Jun 3-6; Curitiba, PR, Brazil. p. 2301-2312.

12. Nagel A, Petzow G, Greil P. Rheology of aqueous silicon nitride suspensions. Journal of the European Ceramic Society. 1989;5(6):371-378

13. Gonzenbach UT, Studart AR, Tervoort E, Gauckler LJ. Stabilization of Foams with inorganic colloidal particles. Langmuir. 2006;22(26):10983-10988.

14. Sousa E, Silveira CB, Fey T, Greil P, Hotza D, Novaes de Oliveira AP. LZSA glass ceramic foams prepared by replication process. Advances in Applied Ceramics. 2005;104(1):22-29.

15. Russell HW. Principles of heat flow in porous insulators. Journal of the American Ceramic Society. 1935;18(1-12):1-5.

16. Askeland DR, Fulay PP, Wright WJ. The Science and Engineering of Materials. Stamford: Cengage Learning; 2011. 